\title{
ENERGY IMPLEMENTATION OF SOLAR PANELS FOR REFRIGERATOR NEEDS LOAD FISHING RESULTS 80 WATT MAXIMUM CAPACITY 20 KG
}

\author{
A. YUNUS NASUTION ${ }^{1 *}$, ADITYA PRATAMA ${ }^{2}$, \\ ${ }^{1}$ Faculty Of Enginnering Muhammadiyah University Of Jakarta, \\ Jl Cempaka Putih Tengah 27,Jakarta Pusat 10510, Indonesia \\ ${ }^{1}$ Faculty Of Enginnering Muhammadiyah University Of Jakarta, \\ Jl Cempaka Putih Tengah 27,Jakarta Pusat 10510, Indonesia
}

\begin{abstract}
The initial problems of fishermen still use their semi-modern catches and still use ice cubes as a cooling medium, due to the lack of innovation in the development of the cooling media caught by fishermen. The implementation of solar panel energy is the beginning for the development of refrigerator power consumption caught by fishermen. The goal is to calculate the cooling load on the refrigerator, calculate the Coefficient of performance $(\mathrm{COP})$ at the refrigerator and the loading factors at the refrigerator, where the average ambient temperature is $34{ }^{\circ} \mathrm{C}$ and the temperature to be achieved is $0^{\circ} \mathrm{C}$, the fisherman results used in the study this is a shrimp with a capacity of $20 \mathrm{~kg}$ and the cooling time is 4 hours. Where the total cooling load value is 244.29 Watt, multiplied by 10\% safety factor, so the overall cooling load is 268.72 Watts, refrigerant mass flow rate is $0.0012 \mathrm{Kg} / \mathrm{s}$, the evaporator capacity is 261 Watt, compressor power is 15.6 Watt, The coefficient of performance (COP) value was 16.73 while for the refrigerant capacity was 0.074 Tons of refrigerant, the loading factors in the study were used to run a refrigerator with 80 Watt power for 4 hours, so that the total refrigerator load was $320 \mathrm{Wh}$ (Watt hour), to produce $320 \mathrm{Wh}$ power is used 2 solar panel modules with a capacity of $50 \mathrm{Wp}$ (Watt Peak), and uses a solar change controller (SCC) with a capacity of $10 \mathrm{~A}$. The output power of the solar panel is influenced by the intensity of the sun's light emitted, from the test obtained an average value the average output of solar panels is 90.6 watts, while the total power generated in 11 test points is 536 watts, the type used is polycrystalline, solar panels battery and inverter capacity must be greater than the refrigerator power consumption, in this study used a $12 \mathrm{~V} 35$ Ah battery capacity and 500 Watt Inverter
\end{abstract}

Keywords : Fisherman Refrigerator Solar panel Refrigerant. 
Nasution, AY. et al. Energy Implementation Of Solar Panels For Refrigerator Needs...

\section{INTRODUCTION}

Refrigerator is a storage room with the hope that the quality of the products stored will last longer. The product temperature entered should be in accordance with the Refrigerator temperature. This is often ignored, so the product's chilling time is not met. To fulfill these requirements, a Refrigerator is needed. which can double as a pre-cooler and a Refrigerator. (Stoecker, 1994)

Room heat load and air freshener load can basically be grouped into sensible heat and latent heat (Sumardi, 2004). The cooling load of a room will determine the capacity of the cooling engine used. There are a number of things that need to be considered in calculating the cooling load of a cooling room, that is, the room temperature difference that will be conditioned by the outer temperture, the structure of the material used in the design, the product to be cooled, and other things that affect the cooling load (Anatychuk and Lukyan.L, 2013)

The opportunity to save energy in an air conditioning system can be done through saving energy on cooling machines and saving energy in the air distribution system. (Sinaga. N, 1984)

Solar power plants actually depend on the efficiency of energy conversion and the concentration of sunlight received by the cell (Awang Riyadi, 2008)

The condition of the area which is located on the coast of Java, most of the population is fishermen. Fishermen in this area are classified as semi-modern, with conventional fishing gear as well as storage (Refrigerator) the catch of the fishermen obtained still uses ice cubes as a cooling medium. Fluctuating fishermen products sometimes make fishermen lose money because income is not worth the expenditure. The consumption of ice cubes which is used as a cooling medium in the cooling room for the results of fishermen is at

\footnotetext{
$1 *$ Corresponding author.

E-mail address: type your email address here
}

least $1 / 4$ beam up to 1 block of ice cubes at a fairly expensive price.

The cycle of the Refrigerator is influenced by the value of the Coefficient Of Performance (COP) of the system. Where the COP value is obtained from the calculation between the effects of refrigeration divided by the work of the compressor, the greater the value of COP, the better the system in the Refrigerator. From the Refrigerator system compressors are used which have a low consumption power, considering the use or application of the Refrigerator for fishermen's catch, which uses solar panel energy, which automatically reserves the power that is smaller than the required power consumption.

\section{EXPERIMENTAL METHOD}

in the announcement of the energy of the solar panels captured by fishermen a flow diagram is made as follows:

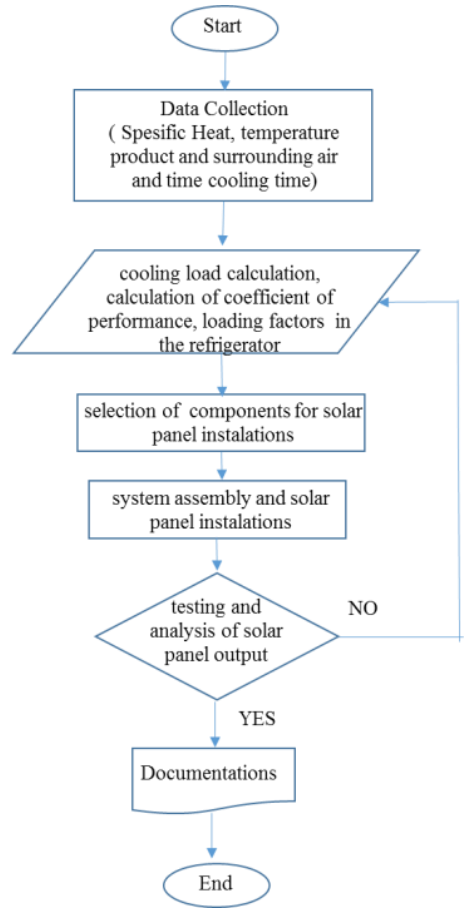

Fig. 1. Flow chart for the implementation of solar panel energy for refrigerators captured by fishermen 
Nasution, AY. et al. Energy Implementation Of Solar Panels For Refrigerator Needs...

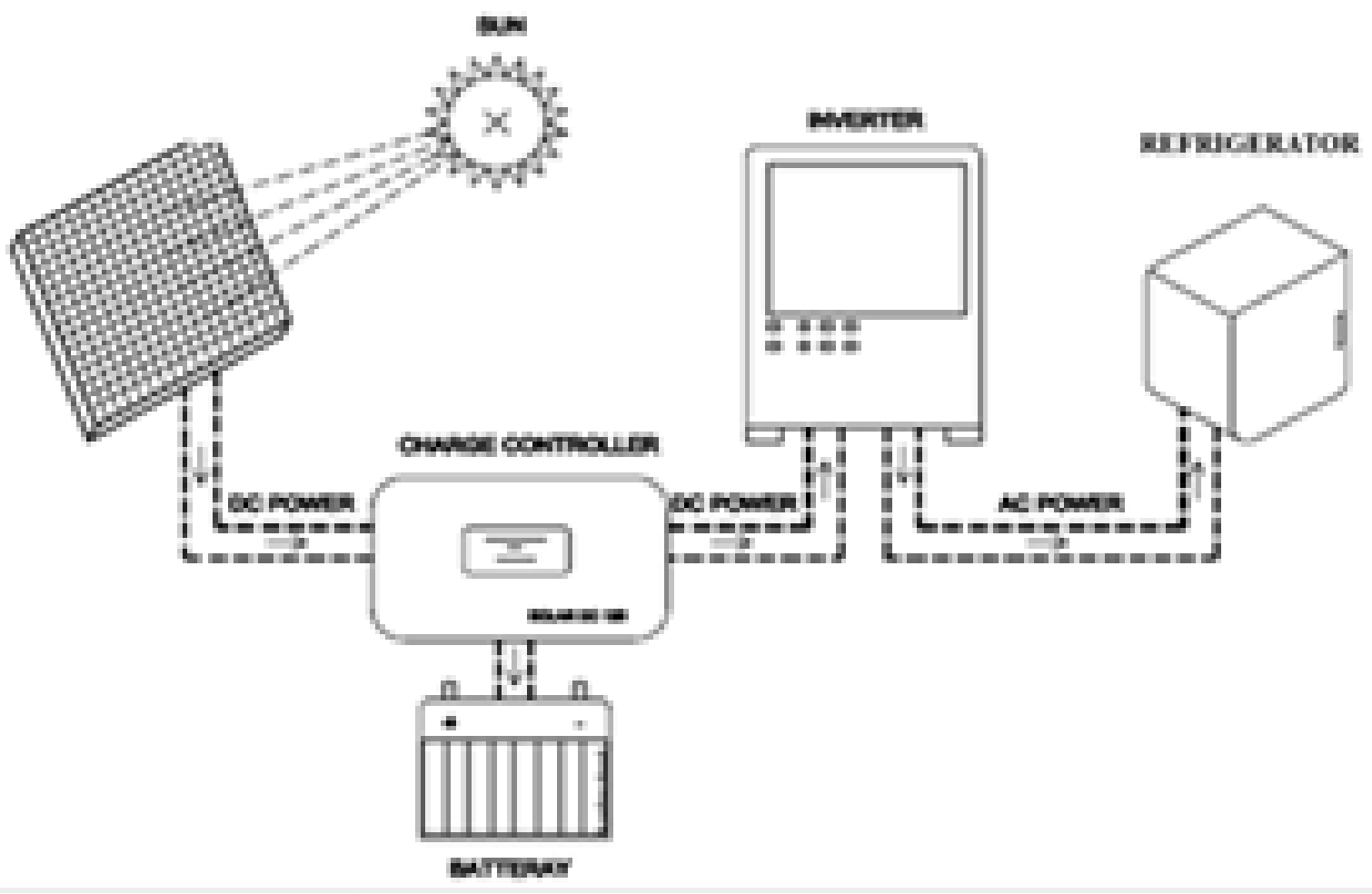

Fig. 2. Installation of a suya panel to run a refrigerator captured by fishermen

\section{RESULTS AND DISCUSSION}

1. Calculation of cooling load on a refrigerator In this study used a refrigerator with panang dimensions of $437 \mathrm{~mm}$, width of $470 \mathrm{~mm}$ and height of $510 \mathrm{~mm}$. The results of fishermen who will be cooled by refrigerators are shrimp with a maximum capacity of $20 \mathrm{~kg}$ and the cooling time is 4 hours. The average wall temperature on the refrigerator is $37 \mathrm{oC}$ while the temperature of the shrimp before entering the refrigerator is $280 \mathrm{C}$. With the material walls used can be seen in table

Table 1. Material layer specifications for refrigerator

\begin{tabular}{|c|c|c|c|}
\hline No & Material & Thickness $(\mathrm{cm})$ & Thermal conductivity W/mK \\
\hline 1 & Carbon Steel & 0.002 & 31,2 \\
\hline 2 & Polyuretane & 0,35 & 0,046 \\
\hline 3 & Alumuium Foil & 0.001 & 120 \\
\hline
\end{tabular}

With data that is already known or obtained, the refrigerator cooling load is calculated

a). External Cooling load

Using equation 1

$Q=A U \Delta T$

.....(1)

First calculate U, using equation 2

$U=\frac{1}{\frac{1}{f_{1}}+\frac{x_{1}}{k_{1}}+\frac{x_{2}}{k_{2}}+\frac{x_{3}}{k_{2}}+\frac{1}{f_{0}}}$

Where ; 
Nasution, AY. et al. Energy Implementation Of Solar Panels For Refrigerator Needs...

$\mathrm{Q}=$ External cooling load (Watt)

$\mathrm{A}=$ Cross-sectional area $\left(\mathrm{m}^{2}\right)$

$\mathrm{U}=$ overall heat transfer efficiency $\left(\mathrm{W} / \mathrm{m}^{2} \mathrm{~K}\right)$

$\Delta T=$ Temperature change $\left({ }^{0} \mathrm{C}\right)$

$\mathrm{K}=$ thermal conducivity material

(watt $/$ m Kwatt $/ m K$ )

$\mathrm{X}=$ Material thickness $(\mathrm{m})$

$f_{1=}$ The air layer coefficient in Value is

$1,65 \mathrm{BTU} / \mathrm{h}=9,27 \mathrm{watt} / \mathrm{m}^{2} \mathrm{~K}$

$1,65 \mathrm{BTU} / \mathrm{h}=9,27 \mathrm{watt} / \mathrm{m}^{2} \mathrm{~K}$

$f_{0} f_{0}=$ Outer air layer coefficient Value is

$4 B T U / h=4 B T U / h=$

22,7 watt $/ m^{2} \mathrm{~K} 22,7$ watt $/ \mathrm{m}^{2} \mathrm{~K}$

Then, the value of $\mathrm{U}$ can be calculated by using equation 2

$U=$

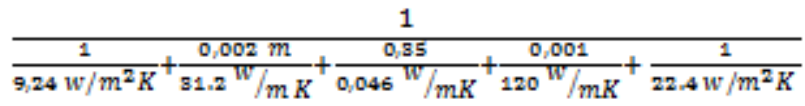

$U=$

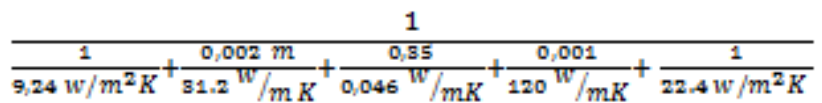

So, $\mathrm{U}=0,128 \mathrm{w} / \mathrm{m}^{2} \mathrm{~K} 0,128 \mathrm{w} / \mathrm{m}^{2} K$

b). Cooling Load of Wall Transmission

Front wall area $=$ back =

$0.51 \mathrm{~m} \times 0.437 \mathrm{~m}=0,22 \mathrm{~m}^{2}$

$0.51 \mathrm{~m} \times 0.437 \mathrm{~m}=0,22 \mathrm{~m}^{2}$

- Lower wall area = top =

$0.51 \mathrm{~m} \times 0.47 \mathrm{~m}=0.24 \mathrm{~m}^{2}$

$0.51 m \times 0.47 m=0.24 \mathrm{~m}^{2}$

- Extent of left wall = right =

$0.47 m \times 0.437 \mathrm{~m}=0,2 \mathrm{~m}^{2}$

$0.47 m \times 0.437 m=0,2 \mathrm{~m}^{2}$

- Total area =

$0,22 \mathrm{~m}^{2}+0,22 \mathrm{~m}^{2}+0.24 \mathrm{~m}^{2}+$

$0.24 \mathrm{~m}^{2}+0,2 \mathrm{~m}^{2}$

$0,22 \mathrm{~m}^{2}+0,22 \mathrm{~m}^{2}+0.24 \mathrm{~m}^{2}+$

$0.24 \mathrm{~m}^{2}+0,2 \mathrm{~m}^{2}$

$+0,2 m^{2}=1,32 m^{2} 0,2 m^{2}=1,32 m^{2}$
So, the transmission load of the wall can be

calculated using equation 1

$Q=A U \Delta T Q=A U \Delta T$

$Q=1,32 \mathrm{~m}^{2} \times 0,128^{\mathrm{w}} / \mathrm{m}^{2}{ }^{\circ} \mathrm{C}$

$Q=1,32 m^{2} \times 0,128 \mathrm{w} / \mathrm{m}^{2}{ }^{\circ} \mathrm{C}$

$x\left(37^{\circ} \mathrm{C}-0^{\circ} \mathrm{C}\right) x\left(37^{\circ} \mathrm{C}-0^{\circ} \mathrm{C}\right)$

$Q=$

$1,32 m^{2} \times 0,128^{\mathrm{W}} / \mathrm{m}^{2 \circ} \mathrm{C}{ }^{x}\left(37^{\circ} \mathrm{C}-\right.$

$0^{\circ} \mathrm{C}$ )

$Q=$

$1,32 m^{2} \times 0,128^{w} / m^{2}{ }^{\circ} \mathrm{C} x\left(37^{\circ} \mathrm{C}-\right.$

$0^{\circ} \mathrm{C}$ )

$Q=6,25 \mathrm{Watt} Q=6,25 \mathrm{Watt}$

c). Internal load

The burden on the part of the refrigerator can be calculated using equation 3 .

$Q=m c \Delta T$

Where $\mathrm{c}$ is the spesific heat of shrimp, based on table 2 , the heat of the type of shrimp is as follows:

Table 2. Heat properties of the product

\begin{tabular}{|c|c|c|c|c|c|c|}
\hline Spenon & $\begin{array}{c}\text { Wontent } \\
\text { Cocted } \\
\text { S }\end{array}$ & $\begin{array}{c}\text { fat } \\
\text { content } \\
5\end{array}$ & 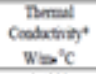 & 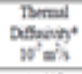 & 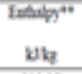 & Spenst Hont \\
\hline Fonda & Ta1s & 3700 & 0.400 & 115007 & 30227 & 3.655 \\
\hline Conart & 9.605 & 0915 & 0.0566 & 16155 & 275.65 & 3.2008 \\
\hline saber & $n 2513$ & $3: 980$ & 0.4711 & 13944 & 30258 & 35954 \\
\hline Sentem & $\times \$ \$ 00$ & 0.253 & 0.050 & 1546 & Mat. & 30 ses \\
\hline Striag & soss & 0091 & 0560 & 1502 & 3645 & 3358 \\
\hline Natend & 73001 & $91 \%$ & 0.06 & 15997 & $322 x$ & 39601 \\
\hline sper & 6.737 & 15934 & 0.0511 & 15417 & 33104 & 33350 \\
\hline Thlop & $n, n$ & Q48) & 0.061 & 19496 & 32:5 & 3513 \\
\hline Thow & $x$ & 2.557 & 0.5186 & 1.64) & 39324 & 3600 \\
\hline Tua & 73.107 & Q016 & Q.40 & 15205 & $2 n$ & 3356 \\
\hline
\end{tabular}

$Q=20 \mathrm{~kg} \times 3,3828^{\mathrm{kj}} / \mathrm{kg} x\left(28^{\circ} \mathrm{C}-0^{\circ} \mathrm{C}\right)$

$Q=1894,368 \mathrm{Kj}$

With a cooling time of 4 hours (14400 seconds), the results of calculating the cooling load divided by the cooling time are as follows: 
Nasution, AY. et al. Energy Implementation Of Solar Panels For Refrigerator Needs...

$$
\begin{aligned}
& \frac{1894,368 \mathrm{Kj}}{14400 \text { detik }}=\frac{1894,368 \mathrm{Kj}}{14400 \text { detik }}=0,13 \mathrm{KW} \\
& \text { Watt) }
\end{aligned}
$$

d). Infiltration Load

Infiltration load is the burden produced by the exchange of outside air (environment) with air in the refrigerator. Infiltration load can be calculated using equation 4 .
Infiltras
change
$(\mathrm{L} / \mathrm{s}) \mathrm{x}$

The infiltration value of load and entrenchment change are obtained in table 3 and table 4

\begin{tabular}{|c|c|c|c|c|c|c|c|c|c|c|}
\hline \multirow{3}{*}{$\begin{array}{l}\text { Storage } \\
\text { Aloom } \\
\text { Temp. ("C) }\end{array}$} & \multicolumn{10}{|c|}{ Inlet air Temo, ("C) } \\
\hline & \multicolumn{3}{|c|}{$25^{\circ} \mathrm{C}$} & \multicolumn{3}{|c|}{$\begin{array}{c}300 \mathrm{C} \\
\text { hate is } \mathrm{BH}(\mathrm{y})\end{array}$} & \multicolumn{2}{|c|}{$35^{\circ} \mathrm{C}$} & \multicolumn{2}{|c|}{$\Delta D^{\circ C}$} \\
\hline & 50 & 60 & 70 & 50 & 60 & 70 & 50 & 60 & 50 & (a) \\
\hline $15 c$ & 0,0128 & 0,0158 & 0,025 & 0,0081 & 0,0657 & 0,0441 & 0,0500 & 0,0683 & 0,0653 & 0,0055 \\
\hline 100 & 0,00666 & 0,0323 & 0,0302 & 0,0319 & 0,0451 & 0,0574 & Q,0591 & 0,0664 & 0,0792 & 0,0982 \\
\hline $5 C$ & 0.0358 & 0,0445 & $0,0,050$ & $0,05 \%$ & 0,0610 & 0,0653 & 0,0008 & 0,0610 & 0,0006 & 0,236 \\
\hline$\alpha$ & 0,0493 & 0,0550 & 0,0606 & 0,0699 & 0,0713 & 0,0754 & 00008 & 0,0910 & 0,1003 & 0,1141 \\
\hline
\end{tabular}

Table 3. parameter for the room temperature enthalpy above $0^{\circ} \mathrm{C} 0^{\circ} \mathrm{C}$

\begin{tabular}{|c|c|c|}
\hline \multirow{2}{*}{$\begin{array}{l}\text { Room Volume } \\
\qquad\left(m^{2}\right)\end{array}$} & \multicolumn{2}{|c|}{ Infiltration load $L / s$} \\
\hline & Rooms Above $\mathrm{O}^{\circ} \mathrm{C}$ & Rooms Below $0^{\circ} \mathrm{C}$ \\
\hline 7 & 3,1 & 2,3 \\
\hline 8.5 & 3,4 & 26 \\
\hline 10 & 3,7 & 28 \\
\hline 15 & 4,4 & 3,3 \\
\hline 20 & 5,0 & 3,8 \\
\hline 25 & 5,0 & 4,2 \\
\hline 30 & 5,5 & 4,6 \\
\hline 40 & 5,9 & 5,4 \\
\hline 50 & 6,8 & 5,8 \\
\hline 75 & 7,5 & 6,9 \\
\hline 100 & 10,2 & 7,9 \\
\hline 150 & 12,2 & 9,8 \\
\hline
\end{tabular}

Table 4. parameter for the Infiltration rate value
So, the value of the infiltration cooling load is as follows:

Qinfitrasi $=$

$1,3 \mathrm{~L} / \mathrm{s} \times 0,0808^{\mathrm{Kj}} / \mathrm{L}$

$1,3 \mathrm{~L} / \mathrm{s} \times 0,0808 \mathrm{Kj} / \mathrm{L}=0,105 \mathrm{Kw}(105,04$

W)

e). Electric Motor Load

Infiltration load is the burden produced by the exchange of outside air (environment) with air in the refrigerator. Infiltration load can be calculated using equation 4 .

$Q m=$ Daya motor $x$ Heat equivalent

$\mathrm{Q}=6 \mathrm{watt} \times \frac{8 \mathrm{jam}}{24 \mathrm{jam}}=2 \mathrm{watt}$

6 watt $x \frac{8 \mathrm{jam}}{24 \mathrm{jam}}=2 \mathrm{watt}$

f). Total cooling load

Total cooling load is the total amount of each load on transmission lines, products, infiltrations and components used in the refrigerator. The total cooling load value can be calculated using equation 6 .

Qtotal = 四

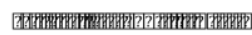

$=6,25$ watt +131 watt $+105,04$ watt +2 watt $=244,29$ watt

Table 5. Recapitulation of Results of Cooling Load Calculation

\begin{tabular}{|c|l|c|}
\hline No & \multicolumn{1}{|c|}{ Source of cooling load } & amount of cooling load (watt) \\
\hline 1 & wall transmission & 6,25 \\
\hline 2 & product load & 131 \\
\hline 3 & infilttration load & 105,04 \\
\hline 4 & electrik motor load & 2 \\
\hline 5 & total cooling load & 244,29 \\
\hline 6 & Factor Safety 10\% & 24,43 \\
\hline 7 & Overall cooling load & 268,72 \\
\hline
\end{tabular}


Nasution, AY. et al. Energy Implementation Of Solar Panels For Refrigerator Needs...

2. Calculation of the Cooling Cycle in the Refrigerator

In calculating the cooling cycle on a refrigerator, the temperature to be cooled is $0^{\circ} \mathrm{C}$ with an ambient air temperature of $34^{\circ} \mathrm{C}$

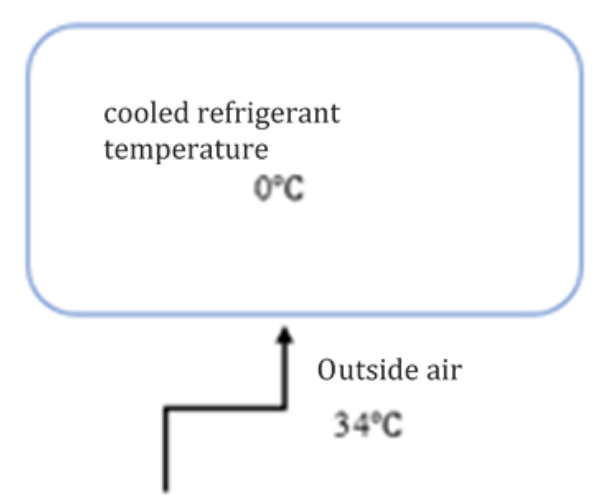

Fig 3. Cooling refrigerant temperature

a). Refrigeration cycle system

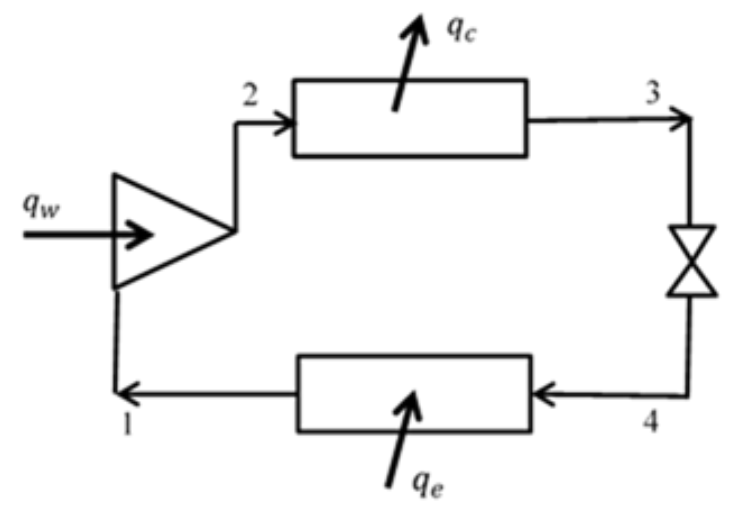

Fig 4. Refrigeration crycle

The conditions in the system above are as follows:

- $\quad$ level of state $1\left(T k_{1} T k_{1}\right)$ saturated steam condition at $34^{\circ} \mathrm{C}{ }^{\circ} \mathrm{C}$, and at state level 2 $\left(T k_{2} T k_{2}\right)$ liquid condition saturated with temperauture $0^{\circ} \mathrm{C}^{\circ} \mathrm{C}$.

- $\quad$ Adiabatic process on the compressor (no heat entering the system)
Flow and level of stationary state (energy does not change to time), $\frac{d E d E}{d t d t}=0$

Different kinetic energy and small potential energy (ignored).

b). Proses statement

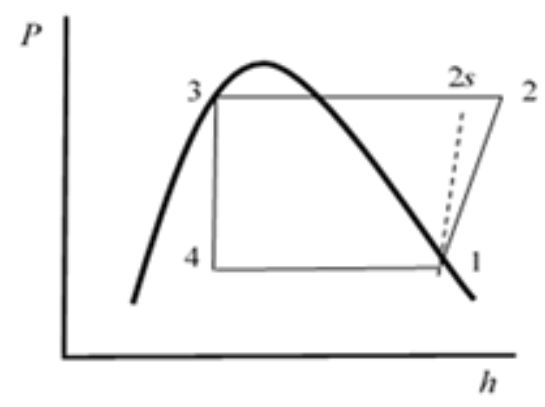

Fig 5. P-h diagram

From the table of properties of refrigerant $\mathrm{R} 134 \mathrm{a}$, and based on the above process conditions, the enthalpy and entropy values are obtained, the values are as follows:

$$
\begin{aligned}
& \text { - Tk1 } \\
& h_{1}=h_{g}=417,5 \mathrm{Kj} / \mathrm{Kg} \\
& h_{3}=h_{f}=200 \mathrm{Kj} / \mathrm{Kg} \\
& s_{3}=s_{f}=1,0000 \mathrm{Kj} / \mathrm{Kg} K \quad \text { dinamic II } \\
& \begin{array}{ll}
s_{2} s= & \dot{\rho}_{s}=\dot{M}\left(s_{2}-s_{1}\right) \\
& \dot{\rho}_{s} \geq 0,\left(s_{2}-s_{1}\right) \geq 0,
\end{array}
\end{aligned}
$$

then it should not be smaller than $s_{1}$, for the occurrence of $\mathrm{h} 2$ as small as possible, then $\mathrm{s}_{2}-$ $\mathrm{s}_{1}$ is used where the second point is $2 \mathrm{~s}$, because of the isentropic process.

c). Calculation of Compressor Work

- Ideal Compressor Work

$$
\begin{aligned}
& (u+P v)_{1}+q_{w}=(u+P v)_{2}+\frac{d E}{d T} \\
& h_{1}+q_{w(s)}=h_{2}+0 \\
& q_{w(s)}=h_{2 s}-h_{1} \\
& q_{w(s)}=430 \frac{K J}{K g}-417,5 \frac{K J}{K g} \\
& q_{w(s)}=13 \frac{K J}{K g}
\end{aligned}
$$


Nasution, AY. et al. Energy Implementation Of Solar Panels For Refrigerator Needs...

Actual compressor work

$$
\eta_{w}=\frac{q_{w(s)}}{q_{w}}=\frac{h_{2 s}-h_{1}}{h_{2}-h_{1}}
$$

Where,

$$
\begin{aligned}
\eta_{w}=80 \% \eta_{w} & =80 \% \\
0,80 & =\frac{13 \mathrm{Kj} / \mathrm{Kg}}{q_{w(a k t)}} \\
q_{w(a k t)} & =\frac{13 \mathrm{Kj} / \mathrm{Kg}}{0,80}=16,25 \mathrm{Kj} / \mathrm{Kg}
\end{aligned}
$$

- $\quad$ Entalpy Station exits

$$
q_{w(a k t)}=h_{2}-h_{1}
$$$$
h_{2}=16,25 \mathrm{KJ} / \mathrm{Kg}+417,5 \mathrm{KJ} / \mathrm{Kg}
$$$$
h_{2}=433,75 \mathrm{KJ} / \mathrm{Kg}
$$

d).Condenser review

$$
(u+P v)_{2}=q_{c}+(u+P v)_{3}+\frac{d E}{d T}
$$$$
h_{2}=q_{c}+h_{3}+0
$$$$
q_{c}=h_{2}-h_{3}
$$$$
q_{c}=433 \frac{K j}{K g}-200 K j / K g
$$$$
q_{c}=233,45 \mathrm{Kj} / \mathrm{Kg}
$$

e). Evaporator review

$$
\begin{aligned}
& (u+P v)_{4}+q_{\theta}=(u+P v)_{1}+\frac{d E}{d T} \\
& h_{4}+q_{\theta}=h_{1}+0 \\
& q_{e}=h_{1}-h_{4} \\
& q_{\theta}=417,5 \frac{K j}{k g}-200 \frac{K j}{K g} \\
& q_{\theta}=217,5 \frac{K j}{K g}
\end{aligned}
$$

f). Mass flow rate

$\dot{m}=\frac{Q_{e}}{q_{e}}$

Where, $Q_{\theta}=Q_{\theta}=$ Total Cooling load $=$ 268,72 Watt

so, the mass flow of refrigerant can be calculated:

$$
\begin{aligned}
& \dot{m}=\frac{0,27 \mathrm{Kj} / \mathrm{s}}{217,5 \mathrm{Kj} / \mathrm{Kg}} \\
& \dot{m}=0,0012 \mathrm{Kg} / \mathrm{s}
\end{aligned}
$$

g). Capacity Evaporator

$$
\begin{aligned}
& Q_{\theta}=\dot{m} \times q_{\theta} \\
& Q_{\theta}=0,0012 \frac{\mathrm{Kg}}{\mathrm{s}} \times 217,5 \frac{\mathrm{Kj}}{\mathrm{Kg}} \\
& Q_{\theta}=0,261 \frac{\mathrm{Kj}}{\mathrm{s}}=261 \mathrm{Watt}
\end{aligned}
$$

h). Compressor Power

$Q_{w}=\dot{m} x q_{w}$

$$
\begin{aligned}
& Q_{w}=0,0012 \frac{\mathrm{Kg}}{\mathrm{s}} \times 13 \frac{\mathrm{Kj}}{\mathrm{Kg}} \\
& Q_{w}=0,0156 \frac{\mathrm{Kj}}{\mathrm{s}}=15,6 \mathrm{Watt}
\end{aligned}
$$

i). Calculation Coefficient of Performance

$$
\begin{aligned}
& \text { COP }=\frac{261 \text { Watt }}{15,6 \text { Watt }} \\
& \text { COP }=16,73
\end{aligned}
$$

j). Calculation Capasity Refrigerant

$$
\begin{aligned}
& Q_{\theta}=261 \text { Watt } x 3,41321 \frac{\text { Btu }}{\text { Watt } h} \\
& Q_{\theta}=890,85 \frac{B t u}{h}
\end{aligned}
$$

So, capacity refrifgerant is 890,85 Btu $/ h 890,85$ Btu $/ h$

$$
\begin{array}{cc}
12000 & 12000
\end{array}=0,074 \text { TR (Ton }
$$


Nasution, AY. et al. Energy Implementation Of Solar Panels For Refrigerator Needs...

Table 6. Recapitulation of Results of Cooling

Cycle Calculation on Refrigerator

\begin{tabular}{|c|l|c|}
\hline No & Calculation Data & The Calculation Results \\
\hline 1 & Ideal compressor work & $13 \mathrm{Kj} / \mathrm{Kg}$ \\
\hline 2 & Actual compressor work & $16,2 \mathrm{Kj} / \mathrm{Kg}$ \\
\hline 3 & Condesner Value & $233,45 \mathrm{Kj} / \mathrm{Kg}$ \\
\hline 4 & Evaporator value & $217,5 \mathrm{Kj} / \mathrm{Kg}$ \\
\hline 5 & Mass flow rate & $0,0012 \mathrm{Kg} / \mathrm{s}$ \\
\hline 6 & Condenser Capasity & $280 \mathrm{Watt}$ \\
\hline 7 & Evaporator Capasity & $261 \mathrm{Watt}$ \\
\hline 8 & Compresor power & $15,6 \mathrm{Watt}$ \\
\hline 9 & Coefficient Of Performance & 16,73 \\
\hline 10 & Refrigerant Capacity & $0,074 \mathrm{TR}$ \\
\hline
\end{tabular}

3. Refrigerator Loading Factors

Loading from the output of solar panels is used to drive a refrigerator with an 80 watt electricity load. In this study used components that can stabilize the output power of the solar panel so that it can work properly.

a). Solar panel used

In this study using polycrystalline type solar panels, considering where fishermen depart at around 5:00 a.m., although in conditions without solar radiation polycrystalline type solar panels still produce voltage so that they can still fill the battrei to be used in the solar panel installation of this study.

In this study using two polycrystalline solar panels with parallel arrangement, so that the resulting electric current is greater.

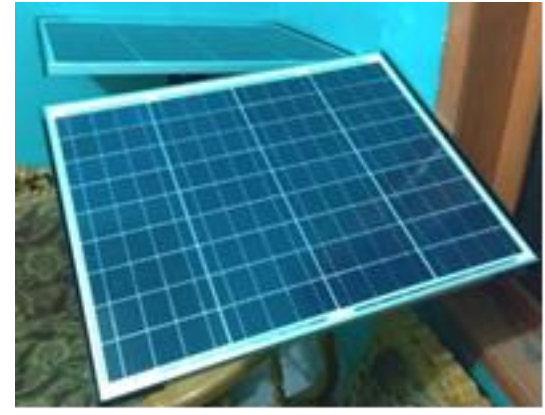

Fig 6. Solar panels with parallel sequences

While the specifications of polycystal solar panels can be seen in Table 7, using the capacity of solar panels each $50 \mathrm{WP}$ (watt peak).

Table 7. Solar panel specification

\begin{tabular}{|l|l|}
\hline ModelNo & SW50P \\
\hline Series No & 812170935132 \\
\hline Peak Power/Pmax (W) & $50 \mathrm{~W}$ \\
\hline Power Tolerance Range & $0-3 \mathrm{~W}$ \\
\hline Open Cicuit Voltage/Voc (V) & $22,1 \mathrm{~V}$ \\
\hline Rated Voltage/Vmpp (V) & $18,2 \mathrm{~V}$ \\
\hline Short Circuit Current /sc (A) & $2,96 \mathrm{~A}$ \\
\hline Rated CurrentImpp (A) & $2,75 \mathrm{~A}$ \\
\hline Max SystemVoltage (V) & $600 \mathrm{Vdc}$ \\
\hline Dimensi (mm) & $660 * 530 * 20$ \\
\hline Weight (Kg) & $3,7 \mathrm{Kg}$ \\
\hline Series Fuse Rating (A) & $10 \mathrm{~A}$ \\
\hline Application Class & $\mathrm{A}$ \\
\hline
\end{tabular}

Calculation of the capacity of solar panels needed to supply power used for the needs of a refrigerator with a load of 80 Watts, here is a calculation to determine the capacity of solar panels:

- Refrigerator load

$=80$ Watt dipakai selama 4 jam

$=80$ watt $\mathrm{x} 4$ jam $=320 \mathrm{Wh}$ (watt hour) 
Nasution, AY. et al. Energy Implementation Of Solar Panels For Refrigerator Needs...

The need for solar panels is used for 4 hours with a capacity of 1 solar panel is 50 Wp (Watt peak).

So, the need for solar panels is $=1.6$ solar panels or 2 solar panels with a capacity of 50 $\mathrm{Wp}$

Table 8. Effect of light intensity on solar panel power output

\begin{tabular}{|c|c|c|c|}
\hline Time & light intensity & Ouput Voltage (Volt) & Ampere $(A)$ \\
\hline $06: 00-7: 00$ WIB & 352 & 20,0 & 0,87 \\
\hline $07: 00-8: 00$ WIB & 843 & 19,8 & 0,86 \\
\hline 08:00-9:00 WIB & 1000 & 20,3 & 1,13 \\
\hline 09:00-10:00 WIB & 1300 & 20 & 1,3 \\
\hline 10:00-11:00 WIB & 1520 & 20,2 & 2,65 \\
\hline $11: 00-12: 00$ WIB & 2150 & 20,0 & 4,52 \\
\hline 12:00-13:00 WIB & 2100 & 19,8 & 4,00 \\
\hline 13:00-14:00 WIB & 1990 & 19,7 & 3,45 \\
\hline 14:00-15:00 WIB & 1400 & 20,1 & 2,87 \\
\hline 15:00-16:00 WIB & 1075 & 20,0 & 2,01 \\
\hline $16: 00-17: 00$ WIB & 530 & 19,9 & 0,96 \\
\hline
\end{tabular}

In table 8, it can be seen at 11: 00-12: 00 WIB having the greatest sunlight intensity with a value of 2150 , with a voltage value reaching $20.0 \mathrm{~V}$ and a strong current of up to $0.52 \mathrm{~A}$, at 06: 00-07: 00 WIB and 16: 00-17: 00WIB there is still the intensity of sunlight with a value of 352 and 530 respectively, and still has a relatively large voltage output and current strength with a voltage value of 19.9 Volt and a strong current of 0,96 This is because the installation of solar panels uses polycrystalline type solar panels arranged in parallel.

The output value of solar panel power is taken one sample, namely at 11: 00-12: 00 WIB, using equation 6 , then the output value of solar panel power per day is as follows:

$P=V \times l P=V \times l$

$P=20 \mathrm{~V} \times 4,53 \mathrm{~A}$

$P=90,6 \mathrm{VA}$

$P=90,6$ (simplified)
With the total power produced by solar panels is to add the value of the output voltage of solar panels and current strength, taken 11 points as seen in table 8 obtained 512 Watt results, with an average power produced per hour is 46.54 Watt.

From these calculations can thus be answered from the research hypothesis with the capacity of $100 \mathrm{Wp}$ solar panels can produce 400 Watts.

b). Solar change controller

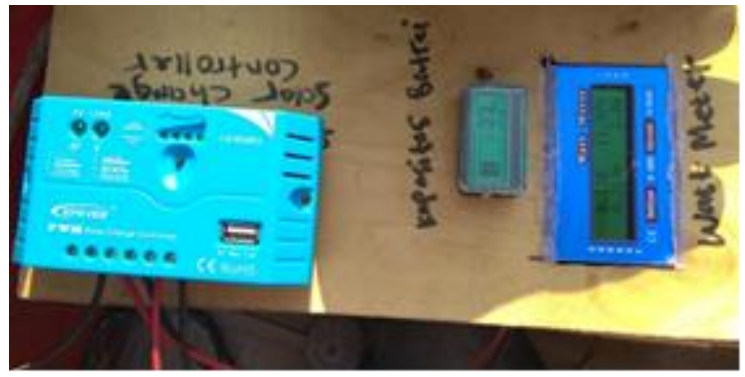

Fig 7. Solar change controller

Uneven sunlight intensity conditions make the output of solar panels unstable, therefore SCC is used to stabilize the output of solar panels, stabilize current and voltage when charging battrei.

In the study of the implementation of solar panel energy for the catch of fishermen using SCC with a capacity of $10 \mathrm{~A}$.

\begin{tabular}{|c|l|c|c|}
\hline No & \multicolumn{1}{|c|}{ Component } & Capasity & Total (pcs) \\
\hline 1 & Polycrystalalline solar panels & 50 Watt Peak & 2 \\
\hline 2 & Solar change controller & 10 Ampere & 1 \\
\hline 3 & Inverter & 500 Watt & 1 \\
\hline 4 & Battery & 12 V 35 Ah & 1 \\
\hline
\end{tabular}

This SCC has 3 outputs and 1 input from the solar panel, and there are also indicators in the form of LED lights so that when a problem occurs it can be detected immediately. In SCC there is also a small button that is used as a switch for output load, so that when the output for the load is not used, the fisherman can press the button and the power produced by the solar panel is not wasted. 
Nasution, AY. et al. Energy Implementation Of Solar Panels For Refrigerator Needs...

c).. Inverter

The inverter is used to convert the voltage from $\mathrm{DC} 12 \mathrm{~V}$ to $\mathrm{AC} 220 \mathrm{~V}$, where this research is shown to drive a refrigerator that consumes around 80 watts of power, to maintain the efficiency or performance of a refrigerator, then an inverter with a larger capacity than solar power consumption is used.

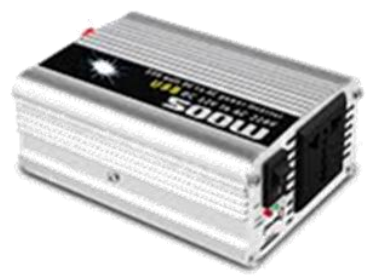

Fig 8. Inverter

In this study used an inverter with a capacity of 500 watts, so that the capacity already represents the energy consumed by the refrigerator.

\section{d). Battery}

Battery in solar panel installations uses secondary battery types, where the type of battery is capable or can be refilled. The solar panel fills the battery capacity which before the power and current output is controlled by the SCC, so that it can maximize long-term use The battery life or battery life can be longer.

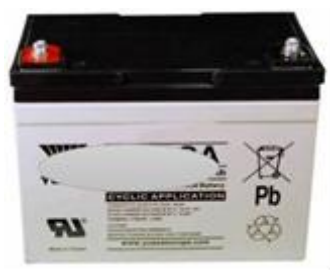

Fig 9 Inverter

In the installation of solar panels using a battery with a capacity of $12 \mathrm{~V} 35 \mathrm{Ah}$, as previously determined the total load consumed by the refrigerator is 80 watts, here is a calculation of the need for the amount of batrei used in solar panel installation;

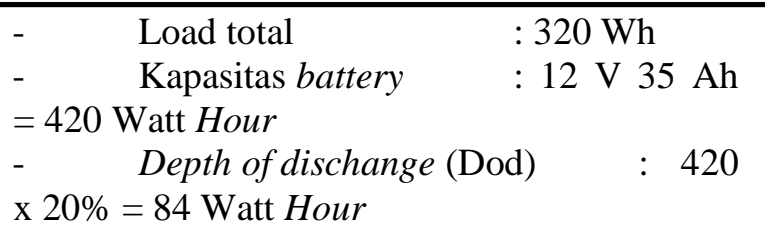

so, the result of battery capacity is 336 Watt Hour

Table 9. Recapitulation of Specifications and Components in Solar Panel Installation

4. Testing solar panel power output The effective time to obtain a large output value of power on solar panels is carried out at intervals between 10:00 WIB - 14:00 WIB, on the results of tests carried out as shown in table 4.6 and the results of the calculation of the average power.

In this test refers to the charging time of battery capacity used and carried out in sun conditions that have a fairly high intensity of sunlight, which is at 11:00. The relationship between battery capacity and the length of filling with no-load conditions as shown in table 9 .

Table 9. Presentase of battery capacity and charging time without load at 11:00 WIB

\begin{tabular}{|c|c|c|}
\hline No & Time (sekon) & Battery Capasicty (\%) \\
\hline 1 & 13 sekon & $40 \%$ \\
\hline 2 & 23 sekon & $50 \%$ \\
\hline 3 & 36 sekon & $60 \%$ \\
\hline 4 & 49 sekon & $70 \%$ \\
\hline 5 & 62 sekon & $80 \%$ \\
\hline 6 & 88 sekon & $100 \%$ \\
\hline
\end{tabular}


Nasution, AY. et al. Energy Implementation Of Solar Panels For Refrigerator Needs...

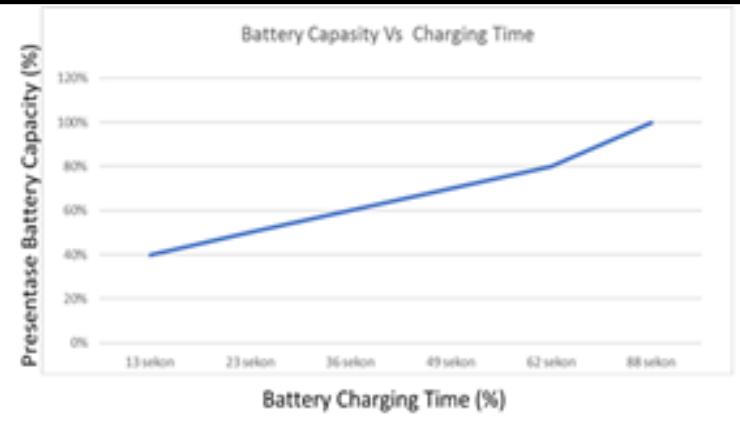

Fig.10. Battery capacity graph Vs charging time

From table 9 it is taken from point 3 that the time needed to fill the $60 \%$ battery capacity takes 36 seconds, to see the increase in battery percentage every time in the test seen in Figure 10.

Judging from the graph above, the increase in the percentage of battery capacity is very important because the intensity of the sun's light is reacted by solar panels to produce electrical power. As for the battery capacity obtained when the sunlight intensity is low at 16:00 WIB, the length of time the battery is charged under no-load conditions is as follows:

Table 10. Presentase of battery capacity and charging time without load at 16:00 WIB

\begin{tabular}{|c|c|c|}
\hline No & Time (minute) & Kapasitas Aki (\%) \\
\hline 1 & 2 minute & $42 \%$ \\
\hline 2 & 4 minute & $56 \%$ \\
\hline 3 & 6 minute & $70 \%$ \\
\hline 4 & 8 minute & $84 \%$ \\
\hline 5 & 10 minute & $100 \%$ \\
\hline
\end{tabular}

In table 10 taken at point 3 to reach $70 \%$ battery capacity it takes about 6 minutes, different from what is shown in table 9 because the test time in table 10 is done at 16:00 WIB, at that time the conditions of solar radiation or sunlight very small, to see the increase in battery percentage each time in the test seen in the graph.

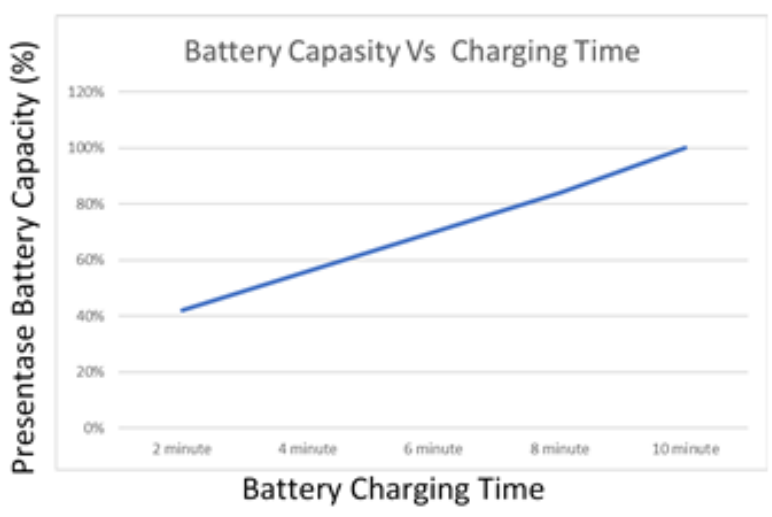

Fig.11. Battery capacity graph Vs charging time

From the graph it can be seen that the battery capacity charged has slowed down, where the charging time from the range of $42 \%-100 \%$ is quite long up to 10 minutes, different from charging batteries at 11:00 WIB, this is influenced by the intensity of sunlight low, so that the output of solar panels to fill the battery also experiences a slowdown in time

If table 9 and 10 tests are carried out to find out the battery capacity to load time with no load, it is different from table 11 where testing is done using an electric load for refrigerator needs of 80 watts, in about 20 minutes testing on moderate sunlight intensity which is around 15:00 WIB. The following is a table of the results of testing the output of solar panels consumed against the percentage of battery capacity. 
Nasution, AY. et al. Energy Implementation Of Solar Panels For Refrigerator Needs...

Table 11. Percentage of battery capacity and charging time with a load of 16:00 WIB

\begin{tabular}{|c|c|c|}
\hline No & Waktu (minute) & Battery Capacity(\%) \\
\hline 1 & 0 minute & $100 \%$ \\
\hline 2 & 10 minute & $52 \%$ \\
\hline 3 & 20 minute & $42 \%$ \\
\hline
\end{tabular}

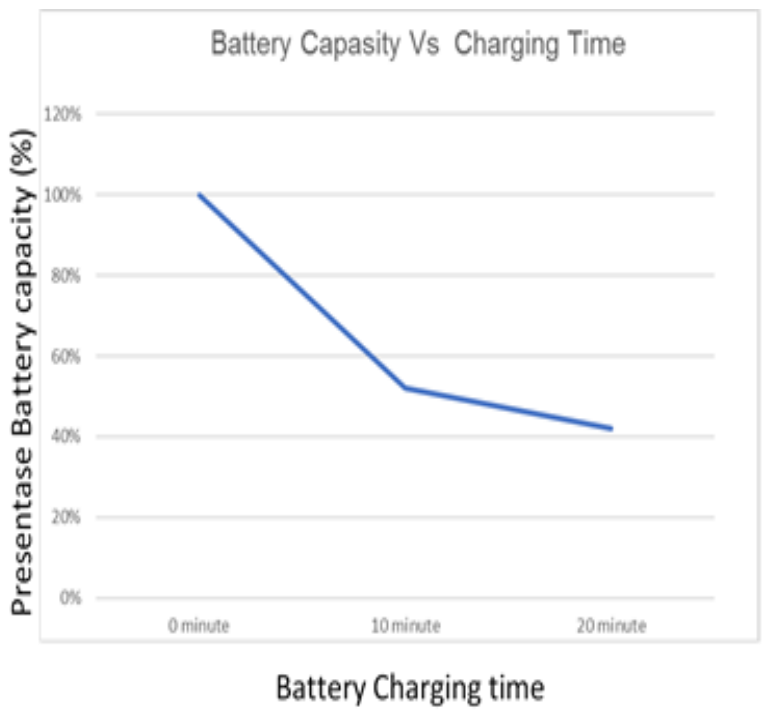

Fig.12. Battery capacity graph Vs charging time

In table 11 the decrease in battery capacity at point 2 is very significant because in this test the refrigerator load is 80 watts, but the decrease from point 2 to 3 decreases the battery capacity to be stable. to see the increase in battery percentage each time in the test seen in the graph

From the graph the decrease in battery capacity percentage has decreased significantly, because the initial power consumption to drive the compressor on the refrigerator does require initial power that must be high, so the power consumed to the percentage of battery capacity in the first 10 minutes is very large, but in the second 10 minutes the capacity decreases battery is very slow. In the second 10 minutes the percentage of battery capacity is only down $10 \%$, this is because the conditions in the refrigerator component are already stable, so the power consumed by the refrigerator is very small.

\section{CONCLUSION}

Based on the following research and testing that has been done, the authors provide conclusions including:

1. The total cooling load contained in the refrigerator is 244.29 watts, while for the overall load of the refrigerator and the multiplication of safety factors with a percentage of $10 \%$, then the overall cooling load results are 268.72 watts, this value is used to calculate the mass flow rate of refrigerants, and then calculate the capacity of each refrigerator component.

2. The value of the Coefficient Of Performance (COP) in the refrigerator cooling cycle is 16.73 based on the assumption of the average temperature of the study on environmental conditions 34 and the temperature of the refrigerator 0 while for the refrigerant capacity of 0.074 Ton Refrigerant.

3. In solar panel installations for the consumption of refrigerators from component catches whose capacity or yield is greater than the electricity load consumed by the refrigerator, where the need for solar panel installations for the needs of refrigerator loads used is a solar panel capacity of 50 Watt peak with the need for 2 solar panels, solar change controller capacity of $10 \mathrm{~A}, 500$ watt inverter and battery $12 \mathrm{v} 35 \mathrm{Ah}$

\section{ACKNOWLEDGMENT}

The author would like to thank the parties who helped in completing this Final Project, including:

1. Thank you to the village head sukahaji has given permission to a writer for did a program devotion based research 
Nasution, AY. et al. Energy Implementation Of Solar Panels For Refrigerator Needs...

2. Thank you to the community and fishers from Sukahaji village what you have been ease and provide input to an author in implementing the program devotion based research

\section{REFERENCES}

1. ASHRAE, Handbook Fundamentals, USA, 1993

2. Astu Pudjasana dan Djati Nursuhud, Mesin Konversi Energi, ANDI, Yogyakarta, 2006

3. Hasyim Asy'ari, Jatmiko, Angga. Intensitas cahaya matahari terhadap keluatan panel surya, UMS, Surakarta, 2012

4. Holman, J. E. Jasifi (penerjemah), Perpindahan panas, Erlangga, Jakarta, 1994

5. Nippodenso, Buku Pedoman dan Pengertahuan $A / C, \mathrm{PT}$ Denso Indonesia.

Jakarta, 2000
6. Roy J Dossat. Principle Of Rferigerant, Jugun Offset, India, 1981

7. Sinaga N, Beberapa peluang penghematan energi pada Gedung berlantai banyak, Jurnal Teknik FT Undip, Edisi Agustus 1994, hal 42-45

8. Stoeker, W.F, dan Jones, J.W, Refrigerasi dan Pengkondisian Udara terjemahan Supratman Hara, Erlangga, Jakarta, 1992

9. Willian C Reynolds dan Henry C Parkins, Termodinamika Teknik terjemahan Filino Harahap, Erlangga, Jakarta, 1991

10. www.Google.co.id/sikluspendingiA/C Mobil

Dilihat pada 14 D esember 2017 pukul 17:00 WIB 